\title{
Fibre quality of South American camelids in Argentina: a review
}

\author{
J.P. Mueller ${ }^{1}$, F. Rigalt ${ }^{1}$, H. Lamas ${ }^{1}$, D.M. Sacchero ${ }^{1}$, A.K. Cancino ${ }^{1}$ and M. Wurzinger ${ }^{2}$ \\ ${ }^{I}$ National Institute for Agricultural Technology (INTA), Argentina; ${ }^{2}$ University of Natural Resources and Life Sciences (BOKU), Austria
}

\begin{abstract}
Summary
Argentina's annual camelid fibre production is estimated at $60000 \mathrm{~kg}$ for llama (Lama glama), somewhat more than $2000 \mathrm{~kg}$ for guanaco (Lama guanicoe) and about $845 \mathrm{~kg}$ for vicuña (Vicugna vicugna). The potential for increasing these amounts is huge considering that barely 30 percent of llamas are shorn and considering the size of the wild camelid population in the country. A compilation of published and unpublished work confirms that almost 50 percent of the llamas are single-coated, about 40 percent have white fleeces and that average fibre diameter is about $22 \mu \mathrm{m}$ in the main llama production area. In general, there is a wide variation in fleece weights and fibre quality between and within herds. However, a llama fleece classing and pricing system is not yet in place to motivate implementation of such programmes. Guanaco and vicuña fleeces are double-coated but the fine undercoat represents more than 80 percent of the fleece weight. The proportion of down fibre remaining after mechanical dehairing is only 50 percent in guanacos and 70 percent in vicuñas. The guanaco undercoat fibre diameter is about $16 \mu \mathrm{m}$ and vicuña fibre diameter is typically between 13 and $14 \mu \mathrm{m}$. Both fibres are relatively short. Research is needed to establish optimum shearing season and shearing frequency that results in fibre quality demanded for handcraft and industry in each of the three species.
\end{abstract}

Keywords: fibre, guanaco, llama, Patagonia, Puna, vicuña

\begin{abstract}
Résumé
La production annuelle de fibres de camélidés de l'Argentine est estimée à $60.000 \mathrm{~kg}$ pour le lama (Lama glama), à un peu plus de $2.000 \mathrm{~kg}$ pour le guanaco (Lama guanicoe) et à environ $845 \mathrm{~kg}$ pour la vigogne (Vicugna vicugna). Le potentiel d'accroissement de ces quantités est énorme compte tenu du fait qu'à peine le 30 pour cent des lamas sont tondus et compte tenu de la taille de la population de camélidés sauvages dans le pays. Une compilation de travaux publiés et non publiés confirme que pratiquement le 50 pour cent des lamas sont à couche unique (sans sous-poil), qu'environ le 40 pour cent ont des toisons blanches et que le diamètre moyen des fibres est de $22 \mu \mathrm{m}$ dans la principale zone d'élevage de lamas. En général, il existe une grande variation inter- e intra-troupeaux dans le poids des toisons et dans la qualité des fibres. Malgré cela, un système de classement et de tarification des toisons des lamas n'a pas encore été mis en place pour motiver la mise en œuvre de ce genre de programmes. Les toisons des guanacos et des vigognes sont à double poil mais la bourre représente plus du 80 pour cent du poids de la toison. La proportion de fibres du duvet restantes après épilage mécanique est seulement du 50 pour cent chez les guanacos et du 70 pour cent chez les vigognes. Le diamètre des fibres du duvet est de $16 \mu \mathrm{m}$ chez le guanaco et de 13-14 $\mu \mathrm{m}$ chez la vigogne. Dans les deux cas, les fibres sont relativement courtes. Des travaux de recherche s'avèrent nécessaires pour déterminer la saison et la fréquence de tonte optimales donnant lieu à la qualité de fibre demandée par les artisans et l'industrie pour chacune des trois espèces.
\end{abstract}

Mots-clés: lama, guanaco, vigogne, la Puna, la Patagonie, fibres

\section{Resumen}

La producción anual de fibras de camélidos en la Argentina se estima en $60.000 \mathrm{~kg}$ de llama (Lama glama), algo más de $2000 \mathrm{~kg}$ de guanaco (Lama guanicoe) y unos $845 \mathrm{~kg}$ de vicuña (Vicugna vicugna). El potencial para aumentar esas cifras es enorme considerando que apenas el 30\% de las llamas son esquiladas y considerando el tamaño de las poblaciones de camélidos silvestres de ese país. En una recopilación de trabajos publicados y trabajos inéditos se confirma que casi el $50 \%$ de las llamas tienen vellones de simple capa, el $40 \%$ de los vellones son blancos y que el promedio de diámetro de fibras es menor a $22 \mu \mathrm{m}$. En general se observa una gran variabilidad en pesos de vellón y en caracteres cualitativos de las fibras entre y dentro de tropas. Sin embargo todavía no hay un sistema de clasificación con precios diferenciales que motive al productor a implementar tales programas de mejora. Los vellones de guanacos y de vicuñas son de doble capa aunque la capa interior representa más del $80 \%$ del peso de vellón. El descerdado mecánico deja solo un $50 \%$ de fibras finas de guanaco y $70 \%$ de fibras finas de vicuñas. El diámetro de fibras de la capa interior de los guanacos es de aproximadamente $16 \mu \mathrm{m}$ y el de vicuñas está entre 13 y $14 \mu \mathrm{m}$. Ambas fibras son relativamente cortas. Es necesario estudiar en los tres camélidos la época y la frecuencia de esquila que resulten en fibra de la calidad demandada por artesanos e industria.

Palabras clave: llama, guanaco, vicuña, Puna, Patagonia, fibra 


\section{Introduction}

South American camelids in Argentina include the domestic llama (Lama glama) and the wild guanaco (Lama guanicoe) and vicuña (Vicuña vicuña) species. Meat and fibre from llamas play an important role in securing food and cash for the most vulnerable rural population in the highlands of the Andes (Paz et al., 2012). Argentina's wild camelid population of guanacos and vicunas is the largest in the world and niche markets are developing for their fibres locally and internationally (Duba, 1999). The potential for expanding cash income from llama fibres and taking advantage from fibre niche markets appears to be big and is largely dependent on the offer of high-quality fibre (Frank et al., 2006a). Quispe et al. (2009) and Cardellino and Mueller (2009) provide general information on South American camelid fibre production in Peru, Bolivia and Argentina. However, characterization of the quality of camelid fibres currently produced in Argentina is partial and circumscribed to specific populations (e.g. Mueller, Elvira and Sacchero, 2013). In view of the interest in designing national and regional development strategies for llama producers (PLC, 2008; MECON, 2010; PGTF, 2013) and the need of updating management programmes for vicuña and guanaco populations (MECON, 2006; Arzamendia, Baldo and Vilá, 2012), it becomes necessary to assess the quantity and quality of the fibre produced by these animal genetic resources in the country. This review examines published information and own unpublished data on domestic and wild camelid fibre quality in Argentina.

\section{Population of camelids}

The last national livestock census dates the year 2002 and indicates that there were 161402 llamas in Argentina (INDEC, 2002). About 68 percent of that population was located in the province of Jujuy, 16 percent in Catamarca, 12 percent in Salta and only 4 percent in other provinces (Figure 1). A survey of 2008 in the North-Western Departments of Jujuy indicated that the llama population had increased since 2002 by 40 percent, largely at the expense of sheep (Roisinblit, 2011) and a study by FAO (2005a) shows that herd size of llamas is larger than reported in the census of 2002. It is estimated that the number of llamas by 2014 is at least 200000 heads, with more than 90 percent reared in the Andean Puna. The Puna is a natural rangeland environment above $3000 \mathrm{~m}$ above sea level occupying much of the province of Jujuy and parts of Salta and Catamarca. One can still find llamas in other, lower altitude and regions of the country, but these are likely to be in commercial or hobby farmer herds rather than in smallholder - low-input systems. It is generally accepted that there are no alpacas (Lama pacos) in Argentina. However, given that there are alpacas in contiguous environments of Chile and Bolivia, there may well be some

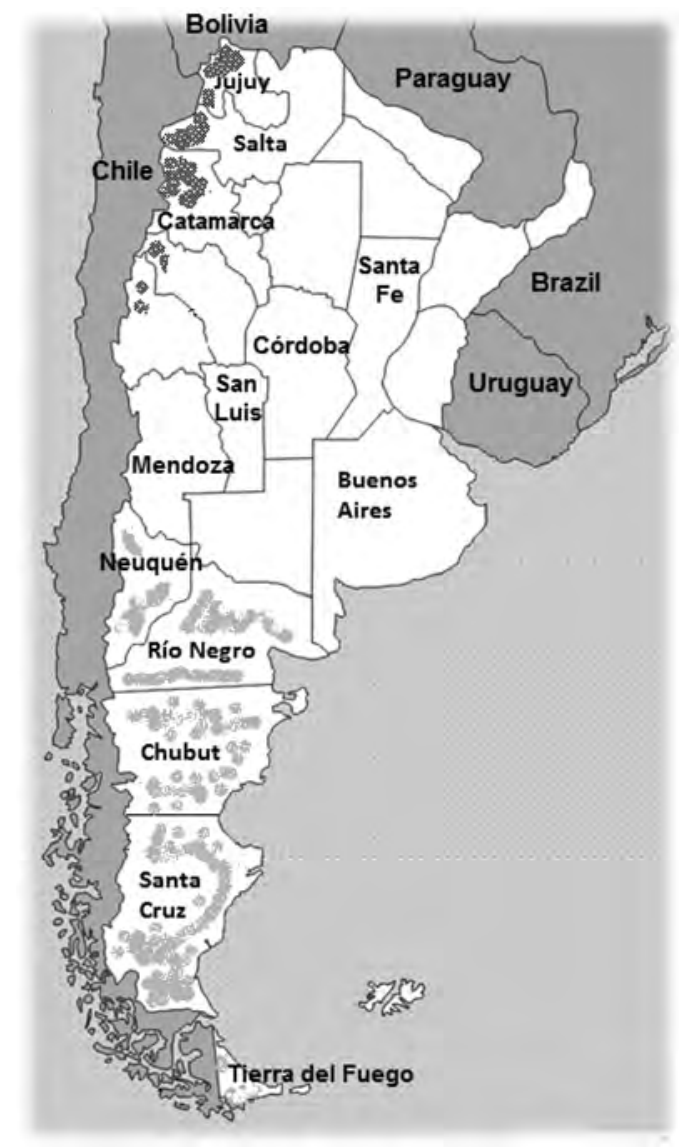

Figure 1. Map of Argentina, including provinces relevant in camelid fibre production or named in the text. Areas with llamas and vicuñas are dark shaded and correspond to "Puna" highland environments of Northern provinces. Areas with guanacos are light shaded and correspond to "Patagonia" desert environments of Southern provinces.

alpacas in Argentina. These alpacas and llamas looking like alpacas, or perhaps crossed with alpacas, the so-called Alpacunos, would be included in the llama population figures.

Together with Peru, Argentina has the largest vicuña population in the world. A comprehensive survey on vicuñas yielded a total number of 131220 animals (CNVG, 2007). This figure is much larger than expected since the previous census of 1980 estimated a population of only half of this number. Vicuñas share the Puna environment with llamas, 42 percent of all vicuñas are located in Jujuy, 31 percent in Catamarca and 19 percent in Salta. Only 8 percent of vicuñas are in other provinces. Guanacos inhabit the cold desert of Patagonia in Southern Argentina. A census carried out in the Patagonian provinces in 2000 estimated a population of 439693 guanacos (Amaya, von Thüngen and De Lamo, 2001), 57 percent in Santa Cruz, 20 percent in Chubut and 23 percent in Río Negro and Neuquén. A recent survey held just in Santa Cruz Province, confirmed a guanaco population between 893307 and 1261755 (Manero et al., 2013). The huge jump in the estimated guanaco population of Santa Cruz may be related to the consequences of the 
eruption of the Hudson volcano in 1991. The ashes from the volcano covered extensive sheep grazing areas forcing the abandonment of farms and therefore facilitating the invasion of wildlife, including guanacos. The perception of experts is that the country's guanaco population may be close to 2 million, by far the largest in the world.

It should be noted that indiscriminate hunting of both camelid species in the past let to a massive reduction of the populations and risk of extinction, especially of vicuñas. Eventually Argentina subscribed the inclusion of guanacos and vicuñas in Appendix II of the "Convention on International Trade in Endangered Species of wild fauna and flora" (CITES). Hence, observing strict protection programmes which ban hunting and control fibre trade. The increasing population size of guanacos and vicuñas can therefore also be related to the successful implementation of the protection programmes. In fact, management programmes are necessary to maintain a balance of population size with available forage resources and other farming activities, such as the predominant sheep production (von Thüngen and Lanari, 2010).

\section{Fibre production}

The production of llamas is concentrated where poverty rate is high (FAO, 2005a). According to the census of 2002 there were a total of 2803 farmers rearing llamas in mixed livestock production systems (INDEC, 2002) along Argentina. Figures from a census performed in 2008 in the province of Jujuy indicate that the number of farmers remained almost the same but the llama population increased 30 percent from 108413 to 140882 (Roisinblit, 2011).

The typical livestock holder in Jujuy runs 161 sheep, 69 llamas, 29 goats and 3 cows (Paz et al., 2012). In the Puna region of Catamarca, a typical farmer holds 70 llamas in addition to about 97 sheep, 101 goats and 64 cattle (PROSAP, 2010). The main product of llamas is meat followed by fibre. In Jujuy raw fibre sales and fibre handcrafts sales contribute about 10 percent to the total income of a household (Paz et al., 2012). The proportion of adult llamas which are shorn in a year varies between 20 and 40 percent, depending on the region, the price of the fibre and the needs of the farmers (Frank and Whebe, 1993). Most fibre collected from skins and from llamas for slaughter is home-used. Since a large proportion of the fibre collected is used within the households or is sold on informal markets, exact figures on the quantity of fibre produced are difficult to assess. It is estimated that the annual amount of llama fibre produced is about 60 $000 \mathrm{~kg}$, including about $20000 \mathrm{~kg}$ home-used fibre (MECON, 2010).

Fibre and hides from vicuñas and guanacos were traditionally used for clothes, construction of shelters, textiles and decorations by indigenous people. Protection programmes were established restricting shearing to live animals under strict control and monitoring by trained wildlife authorities. Vicuña and guanaco fibre from monitored populations can be obtained either from free ranging animals or from animals kept captive in appropriately fenced paddocks. Recent research confirmed that by applying proper welfare protocols during capture and shearing, population demographics of both species are not altered (Arzamendia and Vilá, 2012; Rey et al., 2012). The capture and shearing practices of vicuñas and guanacos kept in captivity were described by Amendolara (2001) and Amaya and von Thüngen (2001), respectively. Whereas the capture and shearing practices of free ranging vicunas and guanacos were described by Rigalt, Sabadzija and Rojas (2006b) and by Lichtenstein and Carmanchahi (2012), respectively. Any farmer or community can start a wild camelid farming enterprise if the corresponding legal requirements are met. These requirements include regular controls of management plans based on population dynamics data which are difficult and expensive to obtain, therefore the actual number of farmers involved in wild camelid fibre harvest is very low. In 2013, there were only 14 farmers rearing vicuñas in captivity (DFS, 2014). In the same year, nine populations of free ranging vicuñas were captured and shorn (DFS, 2014). Owing to the wildlife management controls there are detailed figures on the amount of fibre collected from these legally shorn wild camelids. For example in 2013, a total number of 3623 vicuñas were shorn and $845 \mathrm{~kg}$ of fibre was harvested (DFS, 2014). In 2008, a total number of 6230 guanacos were shorn in 21 capture events and $2117 \mathrm{~kg}$ of fibre was harvested in the two Patagonian provinces of Río Negro and Neuquén (Cancino, 2010, unpublished). For the remaining Patagonian provinces similar quantities of legally obtained guanaco fibre were estimated although guanaco fibre production figures have dropped in recent years. It is estimated that the legally obtained fibre from wild camelids represents only about two-thirds of the total fibre marketed. In any case, wild camelid fibre production is very low but it should be noted that its market price can be very high. For example, raw vicuña fibre averaged 500 USD/kg in public auctions in years 2011-2013. Table 1 shows a summary of current (2013) Argentinean domestic and wild camelid fibre production statistics.

\section{Fleece and fibre traits}

Important characteristics of the fleece and the fibre of camelids are: fleece structure, greasy fleece weight, clean washing yield, fibre colour, proportion of down fibre, mean fibre diameter, variation of down fibre diameter, fibre length and comfort factor (Frank et al., 2006a; Frank, Hick and Adot, 2012). The relative importance of each of these characteristics depends on the camelid species and on the step of fibre marketing and fibre processing considered (McGregor, 2006). For llama farmers fleece 
Table 1. Approximate population size, number of animals shorn, production units and fibre production of domestic and wild camelids in Argentina in 2013.

\begin{tabular}{llrcrr}
\hline Species & Status & Animals & Animals shorn & Producers & Annual fibre production (kg) \\
\hline Llama & Domestic & 200000 & 60000 & 3000 & 60000 \\
Guanaco & Wild & 2000000 & $6000^{1}$ & $20^{2}$ & $2000^{1}$ \\
Vicuña & Wild & 131000 & $3623^{1}$ & $23^{2}$ & $845^{1}$ \\
\hline
\end{tabular}

Source: Mueller et al. (2013) and own updated estimates.

${ }^{1}$ Legally shorn animals and legally marketed fibre.

${ }^{2}$ Management units, including breeding units and regularly captured wild populations.

weight is of major importance followed by fibre colour, fleece structure and mean fibre diameter. Mean fibre diameter is of major importance for the textile industry, followed by fibre length and fibre uniformity. For guanacos and vicuñas fleece weight is the most important trait followed by fibre length and less so the fibre diameter. The methodology used in the assessment of the various fibre traits may differ between studies and should be verified with the original publications. Our own assessments are based on standard methods applied at the INTA Bariloche Textiles fibre Laboratory in Rio Negro, Argentina (Table 2). Whenever appropriate, statistical analyses of own data were performed using mixed models with location, year, sex and age as fixed effects and considering differences in least-squares means significant at $P<0.05$.

\section{Fibre characteristics of llamas}

In Argentina, as well as in Bolivia and Peru, there are two types of llamas. There is the Pelado (or K'ara) type and the Lanudo (or Tamphulli or Ch'aku) type. The two

Table 2. Camelid fibre traits and methodology of its assessment at the INTA Bariloche Textiles Fiber Laboratory in Rio Negro, Argentina.

\begin{tabular}{|c|c|c|c|}
\hline Trait & Abbreviation & Unit & $\begin{array}{l}\text { Assessment } \\
\text { methodology }\end{array}$ \\
\hline $\begin{array}{l}\text { Greasy fleece } \\
\text { weight }\end{array}$ & GFW & g & Scale \\
\hline $\begin{array}{l}\text { Pieces and belly } \\
\text { wool weight }\end{array}$ & PBW & g & Scale \\
\hline Total fleece weight & TFW & $\mathrm{g}$ & $\mathrm{PBW}+\mathrm{GFW}$ \\
\hline Clean washing yield & $\mathrm{CY}$ & $\%$ & $\mathrm{ANZS}^{1}$ \\
\hline Clean fleece weight & CFW & g & $\mathrm{CY}^{*} \mathrm{GFW}$ \\
\hline Down yield & DY & $\%$ & IWTO $58^{2}$ \\
\hline $\begin{array}{l}\text { Medullated fibres } \\
\quad(\text { kemp }+ \text { med })\end{array}$ & Med & $\%$ & IWTO 8 \\
\hline Mean fibre diameter & MFD & $\mu \mathrm{m}$ & IWTO 12 \\
\hline $\begin{array}{l}\text { Coefficient variation } \\
\text { of MFD }\end{array}$ & CVF & $\%$ & IWTO 12 \\
\hline Curvature & Curv & $\mathrm{deg} / \mathrm{mm}$ & IWTO 12 \\
\hline Comfort factor & $\mathrm{CF}$ & $\%$ & IWTO 12 \\
\hline Fibre length & FL & $\mathrm{mm}$ & IWTO 30 \\
\hline Staple length & SL & $\mathrm{mm}$ & Ruler \\
\hline Staple strength & SS & N/ktex & IWTO 30 \\
\hline
\end{tabular}

${ }^{1}$ Australian - New Zealand Standards.

${ }^{2}$ International Wool Textile Organization. types can be differentiated phenotypically by their head, ear insertion and body structure and also by the quantity and quality of their fibre. A genetic base for this phenotypic differentiation is however not yet known (Iñiguez et al., 1998). Pelado llamas have much less fibre on neck and extremities than Lanudo llamas. The Pelado type has a more meat animal body structure and produces less but somewhat finer fibre. The average fleece weight of Pelados under on-farm conditions is seldom higher than $800 \mathrm{~g}$, whereas Lanudos have fleeces weighing more than $1000 \mathrm{~g}$ (Cancino et al., 2006). A comprehensive survey on llama types was undertaken by Hick et al. (2009) covering six sites located between 3500 and 4500 masl in the departments of Santa Catalina, Rinconada, Cochinoca and Yavi of the province of Jujuy. A total number of 10760 animals from 143 herds were included in the study. About 56 percent of all animals were classified as Lanudos, 37 percent as intermediate and the remaining 7 percent were classified as Pelados and Alpacunos. The fleeces of both Pelado and Lanudo llamas may be singlecoated (SC), double-coated (DC) or luster (L). Most Lanudos have single or luster coats and most Pelados have a double coat, but there are also intermediate types. SC fleeces have thick and thin crimped fibres. DC fleeces have highly visible guard fibres and crimped shorter down fibres. Luster fleeces have thick and thin straight fibres in curled staples with a thin tip (Frank, Hick and Adot, 2007). Fleeces in-between SC and L are defined as hemiluster and fleeces in-between SC and DC are defined as intermediates. Following this definitions, Hick et al. (2009) classified 43 percent of llamas surveyed in Jujuy as being SC, 27 percent as DC, 18 percent as hemi-luster and the remaining fleeces as intermediate and luster.

Furthermore, the results of Hick et al. (2009) and Frank et al. (2006a) indicate that according to the coat colour 41 percent of llamas were white, 27 percent were brown or tan coloured and 16 percent chestnut coloured. Only 16 percent were of other colours such as black, grey or mixed. In the province of Catamarca, brown llamas are more common (Rigalt, 2010, unpublished). For example Frank and Nuevo Freire (1985) observed 87 brown (58 percent) and 27 black (15 percent) animals in a herd of 150 llamas in the region of Laguna Blanca in Catamarca.

Hick et al. (2009) classified 50 percent of llamas as superfine $(<21.9 \mu \mathrm{m}), 33$ percent fine $(22-24.9 \mu \mathrm{m}), 14$ percent medium $(25-29.9 \mu \mathrm{m})$ and only 2 percent as coarse $(>30$ 
Table 3. Fibre quality of annually shorn llama males of different ages.

\begin{tabular}{lcccccccc}
\hline Age (years) & $\boldsymbol{N}$ & GFW (g) & CY (\%) & MFD $(\boldsymbol{\mu m})$ & CF (\%) & FL (mm) & Med (\%) & SS (N/ktex) \\
\hline 1 & 56 & 1093 & 91.8 & 20.0 & 93.7 & 128 & 29 & 21.4 \\
2 & 46 & 1200 & 95.3 & 23.8 & 91.5 & 101 & 27 & 24.7 \\
3 & 35 & 1500 & 95.9 & 23.7 & 88.9 & 101 & 32 & 23.8 \\
\hline
\end{tabular}

Source: Cancino et al. (2006).

See abbreviations in Table 2.

$\mu \mathrm{m})$. The weighted average fibre diameter was $22.3 \mu \mathrm{m}$. Frank et al. (2006b) measured $22.9 \mu \mathrm{m}$ in a mixed sex herd of Yavi, Jujuy. In Abra Pampa, Jujuy, Cancino et al. (2006) measured 20.0, 23.8 and $23.4 \mu \mathrm{m}$ in samples collected from male llamas aged 13, 24 and 36 months, respectively. An increase of average fibre diameter with age was also observed by Frank et al. (2006b).

In the province of Catamarca, Frank and Nuevo Freire (1985) obtained a fibre diameter of $26.8 \mu \mathrm{m}$ from a llama herd $(n=70)$ in Laguna Blanca. Rigalt (2010, unpublished) collected samples from eleven llama herds in Laguna Blanca, Antofagasta and Santa María. Fibre diameter ranged $21-25 \mu \mathrm{m}$ and other traits also varied considerably (Table 4).

Away from their traditional rearing environment of the highlands of Jujuy, Salta and Catamarca, there are llama herds in other provinces and at lower altitude. For example, in the province of Neuquén at 800 masl, where summers are frosty and winters are cold with intensive snow cover, a large llama herd is run to produce fibre for a handcraft production company (Cancino 2010, unpublished). The foundation animals of this herd came from the highlands of Jujuy and the overall average fibre diameter of the herd is $24.4 \mu \mathrm{m}(n=661)$. Fibre diameter of males and females at first shearing is $21.8-23.8 \mu \mathrm{m}$ and at second and third shearing between 24.9 and 29.9 $\mu \mathrm{m}$ (Table 5). In milder and more humid environments of the provinces of San Luis and Santa Fe, the fibre diameter of adult llamas is between 23.5 and $27.2 \mu \mathrm{m}$.

Llamas can also be found in other provinces of Argentina such as Río Negro, Córdoba and Buenos Aires. Coates and Ayerza (2004) report fibre quality of llamas in Buenos Aires, which originally were introduced from the highlands. Females and males averaged fibre diameters of 29.3 and $29.0 \mu \mathrm{m}$, respectively. These results for fibre diameter are much higher than figures obtained in the highlands, which might be attributed to the better feeding conditions in this environment and production system.

The observed phenotypic differences within and between herds in fleece weights and fibre diameter and the medium-to-high heritabilities reported for these traits (Wurzinger et al., 2006; Frank et al., 2011) enable successful selective breeding. Llama breeding programmes aimed at improving fibre traits were implemented in Abra Pampa (Jujuy) and in Santa Maria (Catamarca) but the results are not documented. In INTA Abra Pampa, the breeding programme started in 1993 with animals grouped into five coat colour herds. Total herd size by 2013 is 650 breeding animals. Birth weight and weaning weight at the age of 7-8 months are recorded and fleece samples are collected from males at first shearing. Males are selected in three stages. First on uniformity of coat colour and sound body conformation, then selection is based on records of body weight, fleece weight and mean fibre diameter. In a

Table 4. Fibre quality of adult llamas in herds of Catamarca (average \pm SD).

\begin{tabular}{|c|c|c|c|c|c|c|c|c|}
\hline Herd & Altitude (masl) & $n$ & DY (\%) & MFD $(\mu \mathrm{m})$ & CVF (\%) & CF (\%) & Curv (deg/mm) & FL (mm) \\
\hline $\mathrm{L}$ & 3800 & 33 & n.a. & $25.4 \pm 3.7$ & $28.9 \pm 2.4$ & $79.1 \pm 13.8$ & n.a. & $118 \pm 33$ \\
\hline $\mathrm{F}$ & 3400 & 7 & $99.8 \pm 1.3$ & $22.6 \pm 4.4$ & $29.1 \pm 1.8$ & $85.4 \pm 12.9$ & $43.0 \pm 6.0$ & $92 \pm 35$ \\
\hline I & 3300 & 6 & n.a. & $22.5 \pm 2.9$ & $29.8 \pm 2.1$ & $88.8 \pm 7.5$ & n.a. & $128 \pm 22$ \\
\hline $\mathrm{J}$ & 3300 & 17 & n.a. & $22.7 \pm 2.7$ & $25.6 \pm 3.0$ & $89.6 \pm 8.5$ & n.a. & $134 \pm 50$ \\
\hline A & 3200 & 30 & $92.4 \pm 5.8$ & $23.1 \pm 3.1$ & $31.1 \pm 3.4$ & $85.3 \pm 9.2$ & $47.5 \pm 7.7$ & $144 \pm 46$ \\
\hline B & 3200 & 13 & $94.6 \pm 3.1$ & $24.2 \pm 3.4$ & $29.7 \pm 3.0$ & $84.2 \pm 11.4$ & $47.9 \pm 6.2$ & $108 \pm 32$ \\
\hline $\mathrm{H}$ & 3200 & 7 & $89.7 \pm 5.8$ & $21.1 \pm 2.6$ & $28.1 \pm 2.2$ & $91.3 \pm 6.7$ & $43.6 \pm 6.1$ & $121 \pm 27$ \\
\hline $\mathrm{K}$ & 3200 & 36 & n.a. & $25.0 \pm 4.3$ & $28.8 \pm 3.1$ & $78.8 \pm 16.5$ & n.a. & $67 \pm 33$ \\
\hline $\mathrm{C}$ & 1800 & 9 & $94.9 \pm 1.8$ & $23.0 \pm 5.0$ & $31.2 \pm 3.6$ & $83.2 \pm 17.2$ & $48.4 \pm 5.5$ & $129 \pm 49$ \\
\hline $\mathrm{D}$ & 1800 & 11 & $92.0 \pm 4.3$ & $23.0 \pm 3.7$ & $28.0 \pm 1.4$ & $86.0 \pm 11.6$ & $46.0 \pm 8.4$ & $107 \pm 37$ \\
\hline $\mathrm{E}$ & 1800 & 7 & $91.0 \pm 2.1$ & $25.9 \pm 4.0$ & $29.9 \pm 3.2$ & $77.8 \pm 15.2$ & $44.1 \pm 6.2$ & $66 \pm 16$ \\
\hline $\mathrm{G}$ & 1800 & 18 & $91.7 \pm 6.8$ & $22.9 \pm 2.5$ & $29.6 \pm 3.5$ & $87.9 \pm 8.0$ & $50.4 \pm 9.9$ & $66 \pm 24$ \\
\hline Average & & & $93.0 \pm 4.5$ & $23.9 \pm 3.5$ & $29.2 \pm 2.9$ & $83.6 \pm 12.0$ & $47.2 \pm 7.4$ & $106 \pm 36$ \\
\hline
\end{tabular}

Source: Rigalt (2010, unpublished).

n.a.: not available.

See abbreviations in Table 2 . 
Table 5. Fibre quality of llamas in lowland environments.

\begin{tabular}{|c|c|c|c|c|c|c|c|c|c|}
\hline Province & Category & Year & Age & Shearing & $n$ & MFD $(\mu \mathrm{m})$ & CVF (\%) & CF (\%) & FL (mm) \\
\hline Neuquén & Males & 2007 & 2 years & First & 70 & 23.2 & 23.1 & 88.3 & 128.0 \\
\hline Neuquén & Males & 2008 & 2 years & First & 84 & 21.8 & 21.8 & 92.8 & 125.8 \\
\hline Neuquén & Males & 2009 & 2 years & First & 63 & 22.5 & 27.8 & 89.3 & 129.7 \\
\hline Neuquén & Females & 2008 & 2 years & First & 119 & 21.8 & 21.7 & 92.6 & 120.1 \\
\hline Neuquén & Females & 2009 & 2 years & First & 62 & 23.8 & 28.3 & 83.8 & 115.0 \\
\hline Neuquén & Females & 2009 & 4 years & Second & 30 & 24.9 & 27.7 & 83.8 & 107.2 \\
\hline Neuquén & Females & 2009 & 6 years & Third & 36 & 28.2 & 26.7 & 69.4 & 99.2 \\
\hline Neuquén & Females & 2009 & $>6$ years & n.a. & 79 & 28.6 & 27.3 & 67.3 & 95.4 \\
\hline Neuquén & Stud males & 2009 & 4 years & Second & 8 & 25.6 & 25.9 & 81.6 & 115.0 \\
\hline Neuquén & Stud males & 2009 & $>4$ years & n.a. & 12 & 29.9 & 23.7 & 62.3 & 113.2 \\
\hline Neuquén & Stud females & 2009 & 4 years & Second & 16 & 25.8 & 26.7 & 77.2 & 114.1 \\
\hline Neuquén & Stud females & 2009 & $>4$ years & n.a. & 15 & 27.2 & 27.1 & 74.1 & 109.7 \\
\hline Neuquén & Males + females & 2010 & 4 months & First & 67 & 26.2 & 28.0 & 76.8 & 77.1 \\
\hline San Luis & Females & n.a. & Adult & n.a. & 93 & 25.2 & 26.7 & 81.5 & n.a. \\
\hline San Luis & Stud males & n.a. & Adult & n.a. & 17 & 27.2 & 26.7 & 70.8 & n.a. \\
\hline San Luis & Males & n.a. & Adult & n.a. & 19 & 26.3 & 25.9 & 78.0 & n.a. \\
\hline San Luis & Tuis & n.a. & $1-2$ years & n.a. & n.a. & 23.0 & 25.4 & 88.1 & n.a. \\
\hline Santa Fe & Females & n.a. & Adult & n.a. & 43 & 23.4 & 29.6 & 85.2 & 116.0 \\
\hline Santa Fe & Stud males & n.a. & Adult & n.a. & 4 & 23.5 & 29.3 & 85.3 & 93.0 \\
\hline Santa Fe & Not defined & n.a. & n.a. & n.a. & 27 & 22.1 & 30.2 & 88.6 & 176.0 \\
\hline Average & & & & & & 25.0 & 26.5 & 80.8 & 114.7 \\
\hline
\end{tabular}

Source: Cancino (2010, unpublished).

n.a.: not available.

See abbreviations in Table 2 .

third stage, before mating or sale, a final visual inspection is done. Cancino, Rebuffi and Aller (2001b) recorded greasy fleece weights of $1080 \mathrm{~g}(n=74), 1150 \mathrm{~g} \quad(n=$ $48)$ and $1260 \mathrm{~g}(n=13)$ for males from the Abra Pampa base population (general herd) at the age of 1,2 and 3 years, respectively. Selected males in the nucleus had an approximately 10 percent higher fleece weight and better fibre quality than the base population.

\section{Fibre characteristics of guanacos}

Shearing of guanacos is performed with mechanical scissors and usually includes fleece and belly sites, in general only the neck of the animal is left unshorn. It is uncommon that the same free-ranging guanaco is caught for shearing in consecutive years; therefore in a particular shearing event animals with different fibre growth periods are shorn. Shearing season seems not to affect significantly fleece weights but first shearing of an animal yields more fibre than a second shearing of the same animal (von Thüngen et al., 2012). It has been shown that lifetime fibre production is higher with annual shearing's (Cancino et al., 2008). Fleece weight of adult guanacos is in the range $300-700 \mathrm{~g}$ and animals at the age of 1 year have been recorded with fleece weights up to $420 \mathrm{~g}$ (Bacchi, Lanari and von Thüngen, 2010). Guanaco fleeces, such as vicuña fleeces, have two types of fibres: fine and short down fibres and coarse and long guard fibres. Although the guanaco down yield is about 80-90 percent (Table 6) the actual proportion of down fibre obtained after mechanical dehairing is usually only about 50 percent
(Adot, Cossio and Maguire, 2008). Some producers clean the fleeces from soil and vegetable matter, and take out the guard fibres before selling the fleece or submitting for testing. Depending on the cleaning level, the proportion of down fibres measured in the cleaned fraction may increase to values of 65-95 percent (Sacchero, Maurino and Lanari, 2006). Fibre diameter varies between animals and age groups. Bacchi, Lanari and von Thüngen (2010) observed less fibre production (159 versus $254 \mathrm{~g}$ ) and finer fibres $(14.2$ versus $15.0 \mu \mathrm{m})$ in guanaco calves (animals up to 1 year but with primary incisors) than in yearling guanacos (animals 1-2 years of age and with permanent incisors). Sacchero, Maurino and Lanari (2006) reported a fibre diameter ranging between 14.5 and 19.3 $\mu \mathrm{m}$ and a proportion of down fibres between 64.9 and 94.5 percent in seven different guanaco populations of the North of Patagonia. In that study, MFD of the whole sample was compared with the mean fibre diameter of down fibres. Down fibres were only $0.6 \mu \mathrm{m}$ finer than all fibres in the sample. A further study of fibre quality in several guanaco populations is summarized in Table 6. It should be noted that on average the within sample fibre diameter variability $(\mathrm{CVF}=31.3$ percent $)$ is more than four-times the between-animal fibre diameter variability $(\mathrm{CV}$ of $\mathrm{MFD}=7.5$ percent $)$, whereas the between-animal variability in down fibre length is high $(\mathrm{CV}$ of $\mathrm{FL}=27.0$ percent). Llama herds $G$ and $J$ sampled for this study grazed on very poor rangelands and this may explain the particular short fibres measured (Table 6).

In another study, three guanaco populations were investigated and fibre diameters of $14.6 \pm 0.7$ to $16.5 \pm 1.7 \mu \mathrm{m}$ 
Table 6. Fibre quality of adult guanaco herds and its between-animal coefficient of variation (CV, \%).

\begin{tabular}{|c|c|c|c|c|c|c|c|c|c|c|c|}
\hline Province & Herd & Year & $n$ & MFD $(\mu \mathrm{m})$ & $\mathrm{CV}$ & CVF (\%) & $\mathrm{CV}$ & CF (\%) & $\mathrm{CV}$ & FL (mm) & $\mathrm{CV}$ \\
\hline Neuquén & $\mathrm{A}$ & 2005 & 7 & 15.2 & 7.4 & 38.6 & 12.8 & 98.0 & 0.6 & 24.1 & 20.7 \\
\hline Neuquén & A & 2006 & 23 & 16.0 & 6.4 & 33.6 & 14.6 & 98.2 & 0.5 & 24.2 & 22.5 \\
\hline Neuquén & A & 2007 & 83 & 17.3 & 8.4 & 35.7 & 12.3 & 97.3 & 1.5 & n.a. & n.a. \\
\hline Neuquén & B & 2005 & 101 & 15.0 & 5.8 & 36.6 & 14.5 & n.a. & n.a. & n.a. & n.a. \\
\hline Neuquén & B & 2006 & 212 & 15.5 & 7.2 & 38.6 & 18.3 & 97.7 & 1.2 & 28.6 & 27.8 \\
\hline Neuquén & B & 2007 & 218 & 16.3 & 10.0 & 18.7 & 9.6 & 99.7 & 1.0 & n.a. & n.a. \\
\hline Rio Negro & $\mathrm{C}$ & 2005 & 34 & 13.8 & 6.5 & 21.6 & 17.5 & 95.6 & 1.7 & n.a. & n.a. \\
\hline Rio Negro & $\mathrm{C}$ & 2006 & 12 & 15.7 & 5.5 & 45.1 & 8.7 & 97.1 & 0.5 & 35.4 & 25.2 \\
\hline Rio Negro & $\mathrm{D}$ & 2007 & 165 & 17.6 & 8.7 & 35.9 & 11.9 & 97.1 & 1.6 & 20.0 & 22.2 \\
\hline Rio Negro & $\mathrm{E}$ & 2007 & 72 & 15.9 & 5.9 & 35.9 & 13.6 & n.a. & n.a. & 16.8 & 25.6 \\
\hline Rio Negro & $\mathrm{F}$ & 1998 & 36 & 15.5 & 5.3 & 32.8 & 11.1 & n.a. & n.a. & 43.0 & n.a. \\
\hline Rio Negro & $\mathrm{F}$ & 1999 & 7 & 16.2 & 6.9 & 23.2 & 14.9 & 99.3 & 0.3 & 26.4 & 18.5 \\
\hline Rio Negro & $\mathrm{F}$ & 2000 & 13 & 14.6 & 4.9 & 23.6 & 12.2 & 99.6 & 0.2 & 25.5 & 15.1 \\
\hline Rio Negro & $\mathrm{F}$ & 2001 & 104 & 15.6 & 8.2 & 24.5 & 15.2 & 99.1 & 0.6 & 28.4 & 24.6 \\
\hline Rio Negro & $\mathrm{F}$ & 2002 & 89 & 16.0 & 9.8 & 31.8 & 14.9 & n.a. & n.a. & 33.3 & 30.0 \\
\hline Rio Negro & $\mathrm{F}$ & 2004 & 26 & 14.5 & 5.5 & 20.6 & 13.0 & n.a. & n.a. & 35.8 & 28.3 \\
\hline Rio Negro & $\mathrm{F}$ & 2005 & 47 & 15.4 & 6.4 & 24.5 & 22.3 & n.a. & n.a. & 26.0 & 46.3 \\
\hline Rio Negro & $\mathrm{F}$ & 2007 & 130 & 16.6 & 9.6 & 32.7 & 14.4 & 98.1 & 1.0 & n.a. & n.a. \\
\hline Rio Negro & G & 2005 & 10 & 14.9 & 3.8 & 41.4 & 11.0 & 97.8 & 0.4 & 16.6 & 37.4 \\
\hline Rio Negro & G & 2006 & 34 & 15.3 & 5.6 & 37.1 & 10.6 & 97.8 & 0.7 & 23.6 & 24.3 \\
\hline Rio Negro & G & 2007 & 21 & 14.9 & 8.6 & 39.7 & 11.4 & 97.7 & 1.8 & 19.2 & 14.1 \\
\hline Rio Negro & $\mathrm{H}$ & 2007 & 24 & 16.3 & 5.5 & 34.3 & 12.4 & 98.2 & 0.5 & 28.0 & 16.9 \\
\hline Rio Negro & I & 1999 & 13 & 16.3 & 7.9 & 26.6 & 10.3 & n.a. & n.a. & 29.2 & 41.5 \\
\hline Rio Negro & I & 2000 & 19 & 16.3 & 11.9 & 25.1 & 12.7 & n.a. & n.a. & 39.5 & 39.6 \\
\hline Rio Negro & I & 2001 & 19 & 16.4 & 12.2 & 25.5 & 11.1 & n.a. & n.a. & 38.4 & 40.0 \\
\hline Rio Negro & I & 2002 & 18 & 17.0 & 10.4 & 32.0 & 10.0 & n.a. & n.a. & 33.4 & 36.5 \\
\hline Rio Negro & $\mathrm{J}$ & 2004 & 24 & 15.7 & 8.6 & 22.9 & 11.5 & 99.3 & 0.6 & 14.3 & 22.8 \\
\hline Rio Negro & $\mathrm{J}$ & 2006 & 9 & 16.7 & 9.3 & 36.1 & 20.4 & n.a. & n.a. & 16.9 & 16.8 \\
\hline Santa Cruz & $\mathrm{K}$ & 1999 & 27 & 14.7 & 5.6 & 31.8 & 13.4 & n.a. & n.a. & 38.0 & 23.8 \\
\hline Average & & & & 15.8 & 7.5 & 31.3 & 13.3 & 98.1 & 0.9 & 27.7 & 27.0 \\
\hline
\end{tabular}

Source: Sacchero and Cancino (2013, unpublished).

n.a.: not available.

See abbreviations in Table 2 .

and fibre length of $14.4 \pm 3.3$ to $38.1 \pm 9.1 \mathrm{~mm}$ were recorded (von Thüngen et al., 2005). A project run by a smallholder cooperative in the province of Mendoza managed to shear a total of 569 guanacos captured in 12 roundups in the period 2005-2010 and obtained $208.5 \mathrm{~kg}$ fibre with an average fibre diameter of $15.8 \mu \mathrm{m}$ and fibre length of $36 \mathrm{~mm}$ (Lichtenstein and Carmanchahi, 2012). It should be noted that in some years of this study the belly area of the animals were left unshorn.

\section{Fibre characteristics of vicuñas}

Vicuñas are either shorn with scissors or with electrical or mechanical shearing equipment. It is thought that shearing with scissors or shearing only part of the animal's body reduces the risk of cold-stress but there is no research confirming this. There are also accounts on higher (up to $100 \mathrm{~g}$ more) fibre harvest from mechanically shorn animals rather than from animals shorn with scissors, although mechanical shearing is said to yield more contaminated fibre. For the subspecies Vicugna vicugna vicugna, which is the one present in Argentina, extensive information on the fibre characteristics is available from a herd kept in captivity at the INTA Abra Pampa experimental station (Rebuffi,
1999). The herd was established in 1965 with only 16 animals captured in the wild, but since then the number has increased to almost 1300 . Animals from this herd are distributed to private farmers interested in starting a commercial herd. Vicuña fibre from this station is sold to local artisans and to dehairing companies which export the processed fibre. Results from the INTA Abra Pampa herd show average MFD of $13.4 \mu \mathrm{m}$ and FL of $47.3 \mathrm{~mm}$ with a high range of values between animals (Table 7). Additional information from this herd and Catamarca populations is summarized in Table 8. The Catamarca data were analysed for year and sex effect. Year effects resulted significant $(P<0.05)$ only for MFD and CVF; sex was not significant for any trait.

Figure 2 shows the development of total greasy fleece weight and fibre fineness in males according to the age of first shearing. A clear trend in increasing fleece weight with age can be observed. The linear regression shows an increase of $15.6 \mathrm{~g} /$ year $\left(r^{2}=0.97\right)$. On the other hand the increase of fibre diameter with age is very low and seems to disappear at the age of 7-8 years. In later studies of the same herd, average fibre diameters of $13.8 \mu \mathrm{m}$ (SD $3.0 \mu \mathrm{m})$ for de-haired samples and $14.1 \mu \mathrm{m}$ (SD $4.5 \mu \mathrm{m})$ from complete samples were recorded (Sacchero and 
Table 7. Fibre characteristics at first shearing of male vicuñas in Abra Pampa.

\begin{tabular}{lcccc}
\hline Trait & $\boldsymbol{n}$ & Average & Minimum & Maximum \\
\hline Greasy fleece weight (g) & 232 & 201 & 90 & 430 \\
Clean fleece weight (g) & 225 & 178 & 81 & 389 \\
Pieces and belly wool (g) & 232 & 111 & 20 & 235 \\
Total fleece weight (g) & 232 & 312 & 120 & 580 \\
Staple length (mm) & 225 & 49.7 & 25 & 80 \\
Fibre length (mm) & 217 & 47.3 & 25 & 71 \\
Clean yield (\%) & 225 & 88.0 & 77.2 & 97.5 \\
Mean fibre diameter ( $\mu$ m) & 229 & 13.4 & 11.8 & 15.6 \\
Comfort factor (\%) & 229 & 99.0 & 99.9 & 96.9 \\
Continuous medullated & 172 & 1.82 & 0 & 9 \\
$\quad$ fibres (\%) & & & & \\
Discontinuous medullated & 172 & 4.26 & 0 & 25 \\
$\quad$ fibres (\%) & & & & 7 \\
Kemp fibres (\%) & 172 & 1.89 & 0 & 100 \\
Normal fibres (\%) & 172 & 92.0 & 72 & 89.3 \\
Staple strength (N/ktex) & 96 & 46.3 & 11.4 & \\
\hline
\end{tabular}

Source: Adapted from Rebuffi (1999).

Mueller, 2005). The difference being small given that down yield of vicuñas is above 85 percent (Tables 7 and 8 ) and few guard fibres contribute to increase fibre diameter. Mechanical dehaired vicuña fibre yields about 70 percent of down fibre (Adot, Cossio and Maguire, 2008).

Cancino, Rebuffi and Aller (2001a) analysed data from vicuñas reared in captive systems by private producers. In vicuña males, a range in fibre diameter between 11.9 and $22.0 \mu \mathrm{m}$ with an average value of $13.6 \mu \mathrm{m}$ (SD 4.0 $\mu \mathrm{m})$ was observed. Production data per year of shearing and sex of animals from different producers are presented in Table 9. Note that these animals were shorn in a bi-annual interval. In Table 10, the effect of successive bi-annual shearing of the same animals is presented. One can observe that the fibre length remains more or less constant after the first shearing and females produce in general less fibre than males and castrated males.

Information on different fibre traits from vicuñas captured in the wild is still very scarce. Captures of wild vicuñas were organized by the Laguna Blanca community in Catamarca in the years 2003, 2004 and 2005. In these occasions greasy fleece weight from 169, 77 and 93 animals was measured and resulted 206, 286 and $313 \mathrm{~g}$, respectively (Rigalt, Sabadzija and Rojas, 2006b). Rigalt et al. (2006a) took fleece samples from 61 of these vicuñas and recorded an average fibre diameter of 12.6 $\mu \mathrm{m}(\mathrm{SD} 4.4 \mu \mathrm{m})$ and fibre length in the laboratory of 37.7 and $31.0 \mathrm{~mm}$ measured in the field with a ruler. Only animals, which were not shorn in the previous year, were included in the shearing. In captures of vicuñas from populations in higher altitudes (3 800 masl) in the year 2008 and 2009 values for greasy fleece weight exceeded the average values from Abra Pampa and Laguna Blanca (3 200 masl), with similar fibre diameter but longer staples. For example in Laguna Colorada (3 650 masl), the average greasy fleece weight of 207 animals reached 460 $\mathrm{g}$, with some animals even reaching $1000 \mathrm{~g}$. One possible explanation for this could be that the lower temperature at higher altitudes induces more fibre production, but research is needed to determine possible confounded effects such as feed availability or body size.

\section{Discussion}

\section{Argentine camelid fibre quality in perspective}

From the available data some general observations and particularities of Argentinian llama fibres can be made. Almost half of the llamas are of the SC Lanudo type, whereas less than a quarter is of the double-coated, low fibre producing Pelado type. The advantage of SC animals is that dehairing efforts can be reduced, the fine fibre yield is higher and therefore the value of their fleece is higher. This contrasts findings in Bolivia where 74.4 percent of llamas were reported to be of the Pelado type (FAO, 2005b). It should be noted however that there are also llama populations in Bolivia and Peru with similar characteristics of the Argentinean highland llama populations (Maquera, 1991; Martinez, Iniguez and Rodríguez, 1995; Iñiguez et al., 1998; Stemmer et al., 2005). One important feature of the fibre from Argentinian llamas is that although white colour is predominant a wide range of colours is covered. A survey indicated that black, white and grey fibre fetch best prices (PROSAP, 2010). More than 80 percent of the Argentinian llama fibre is finer than $24 \mu \mathrm{m}$ (Hick et al., 2009), which is equivalent to the Peruvian "superfine" $(21-24 \mu \mathrm{m})$ class of commercial alpaca fibre. In comparison only 10 percent of Huacaya alpacas of Australian herds have fibre diameter below $24 \mu \mathrm{m}$ (McGregor, 2006).

Table 8. Fibre quality of adult vicuñas and its between-animal coefficient of variation (CV, \%).

\begin{tabular}{|c|c|c|c|c|c|c|c|c|c|c|c|c|}
\hline Location & Year & $n$ & MFD $(\mu \mathrm{m})$ & $\mathrm{CV}$ & CVF (\%) & $\mathrm{CV}$ & CF (\%) & $\mathrm{CV}$ & DY (\%) & $\mathrm{CV}$ & SL (mm) & $\mathrm{CV}$ \\
\hline \multirow[t]{2}{*}{ Abra Pampa } & 2012 & 132 & 12.8 & 10.0 & 39.1 & 22.5 & 99.0 & 0.5 & 83.3 & 9.0 & 34.7 & 16.6 \\
\hline & 2014 & 65 & 13.9 & 10.1 & 45.6 & 10.8 & 98.6 & 1.4 & 82.7 & 7.5 & 34.5 & 10.0 \\
\hline \multirow[t]{2}{*}{ Catamarca } & 2011 & 93 & 12.1 & 6.8 & 37.1 & 22.3 & 99.1 & 0.9 & 86.0 & 8.7 & n.a. & n.a. \\
\hline & 2014 & 21 & 12.8 & 7.4 & 27.8 & 22.6 & 99.5 & 0.5 & 91.2 & 6.2 & 30.8 & 27.9 \\
\hline
\end{tabular}

Source: Sacchero, Lamas and Rigalt (2014, unpublished).

n.a.: not available.

See abbreviations in Table 2. 


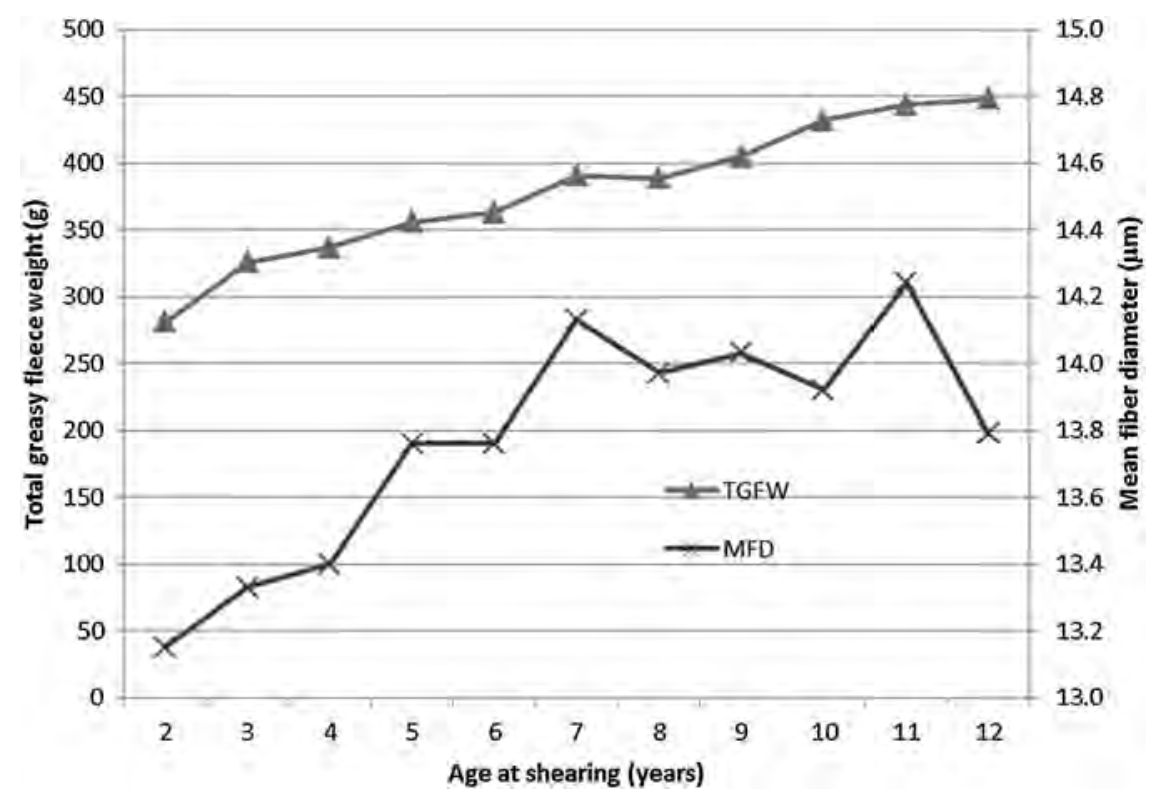

Figure 2. Total greasy fleece weight and mean fibre diameter in male vicuñas shorn for the first time at different ages. Source: adapted from Rebuffi (1999).

Standard deviations in fibre quality traits across different herds and groups of animals are large. For example, the between animals coefficient of variation for fibre diameter in 12 different llama herds (Table 4 ) is on average about 15 percent (3.5/23.9). This is high if compared with the coefficient of variation for wool fibre diameter in sheep. One possible explanation for this large $\mathrm{CV}$ is that animals of different ages are included in the llama sampling, but it also can be a result of low selection pressure for uniformity.

Fibre length can be an issue and one of the problems in analysing reports on fibre length is that in many cases the growth period is not mentioned and in some other cases it is not clear if the fibre samples have undergone a manual dehairing before analysis. Standard IWTO 12 procedures are based on samples without previous dehairing. However, for example, results reported by Siguayro and Aliaga (2009) on fibre quality from Pelado-type llamas from Peru are based on previously dehaired samples. Eliminating kemp fibres from the raw fibre sample reduces the fibre diameter of the remaining fibre by $1-2 \mu \mathrm{m}$. Coates and Ayerza (2004) also discuss this sample preparation procedure as a possible source for differences between populations.

Little information is available on fibre quality of wild camelid populations in other countries. Quispe et al. (2010)

Table 9. Vicuña fibre production of private producers according to year and sex.

\begin{tabular}{|c|c|c|c|c|c|c|c|}
\hline Year & Producers & Category & $n$ & GFW (g) & PBW (g) & TFW (g) & FL (mm) \\
\hline \multirow[t]{3}{*}{1995} & 2 & Males & 5 & 301 & 83 & 384 & 37 \\
\hline & & Females & 15 & 270 & 91 & 361 & 35 \\
\hline & & Castrated & 24 & 274 & 91 & 364 & 32 \\
\hline \multirow[t]{3}{*}{1997} & 10 & Males & 103 & 204 & 147 & 351 & 46 \\
\hline & & Females & 84 & 207 & 150 & 357 & 47 \\
\hline & & Castrated & 23 & 216 & 213 & 429 & 49 \\
\hline \multirow[t]{3}{*}{1998} & 5 & Males & 6 & 160 & 135 & 295 & 50 \\
\hline & & Females & 57 & 145 & 166 & 311 & 47 \\
\hline & & Castrated & 1 & 215 & 195 & 410 & 35 \\
\hline \multirow[t]{3}{*}{1999} & 11 & Males & 31 & 209 & 122 & 331 & 39 \\
\hline & & Females & 74 & 216 & 118 & 334 & 39 \\
\hline & & Castrated & 116 & 236 & 125 & 361 & 40 \\
\hline \multirow[t]{3}{*}{2000} & 5 & Males & 14 & 210 & 124 & 334 & 50 \\
\hline & & Females & 51 & 205 & 120 & 325 & 39 \\
\hline & & Castrated & 33 & 224 & 131 & 355 & 43 \\
\hline \multirow[t]{3}{*}{2001} & 10 & Males & 48 & 173 & 144 & 317 & 40 \\
\hline & & Females & 114 & 172 & 139 & 311 & 39 \\
\hline & & Castrated & 54 & 199 & 170 & 369 & 39 \\
\hline
\end{tabular}

Source: Cancino et al. (2001a).

See abbreviations in Table 2 . 
Table 10. Fibre production of vicuñas according to sex and shearing stage (bi-annual) in private herds.

\begin{tabular}{|c|c|c|c|c|c|c|c|c|c|c|c|c|}
\hline \multirow{2}{*}{$\begin{array}{l}\text { Shearing } \\
\text { stage }\end{array}$} & \multicolumn{4}{|c|}{ Males $(n=44)$} & \multicolumn{4}{|c|}{ Females $(n=162)$} & \multicolumn{4}{|c|}{ Castrated $(n=79)$} \\
\hline & $\begin{array}{c}\text { GFW } \\
\text { (g) }\end{array}$ & $\begin{array}{c}\text { PBW } \\
\text { (g) }\end{array}$ & $\begin{array}{c}\text { TFW } \\
\text { (g) }\end{array}$ & $\begin{array}{c}\text { SL } \\
(\mathbf{m m})\end{array}$ & $\begin{array}{c}\text { GFW } \\
\text { (g) }\end{array}$ & $\begin{array}{c}\text { PBW } \\
\text { (g) }\end{array}$ & $\begin{array}{c}\text { TFW } \\
\text { (g) }\end{array}$ & $\begin{array}{c}\text { SL } \\
(\mathbf{m m})\end{array}$ & $\begin{array}{c}\text { GFW } \\
\text { (g) }\end{array}$ & $\begin{array}{l}\text { PBW } \\
\text { (g) }\end{array}$ & $\begin{array}{c}\text { TFW } \\
\text { (g) }\end{array}$ & $\begin{array}{c}\text { SL } \\
(\mathbf{m m})\end{array}$ \\
\hline First & 186 & 128 & 314 & 48 & 201 & 130 & 329 & 43 & 265 & 133 & 398 & 43 \\
\hline Second & 204 & 130 & 334 & 38 & 183 & 130 & 310 & 35 & 203 & 173 & 376 & 37 \\
\hline Third & 205 & 137 & 340 & 37 & 162 & 140 & 297 & 33 & 218 & 141 & 359 & 37 \\
\hline Fourth & 217 & 118 & 335 & 40 & 196 & 121 & 317 & 38 & 276 & 170 & 446 & 39 \\
\hline
\end{tabular}

Source: Cancino et al. (2001a).

See abbreviations in Table 2.

sampled vicuñas in Huancavelica, Peru at 4600 masl and obtained GFW of $189.7 \mathrm{~g}$ which is considerably less than most fleeces weighted in the Argentinian Puna. Fibre length in Huancavelica was $30.9 \mathrm{~mm}$, MFD was $13.2 \mu \mathrm{m}(\mathrm{CV}$ 19.5 percent) and fibre curvature was $79.9 \mathrm{deg} / \mathrm{mm}$. The lower fleece weights and shorter fibre length in this population compared to the figures from the Puna may be related to differences in the environment but also due to differences in the shearing system and fibre conditioning.

\section{Improvement of camelid fibre quality}

Fibre quality depends on several environmental and genetic factors. In low-input systems farmers have limited control over forage supply but can adjust shearing procedures to improve fibre quality. For example shearing on clean surface and basic conditioning and skirting as well as packing can considerably improve fibre offered. Fibre growth in llamas grazing Puna rangelands is affected by nutritional restrictions from July to October. If shearing is annual and during this period, instead of the regular shearing date of November, the breaking point of the fibres, due to nutritional stress, would be closer to the extremes of the fibre and therefore the effective fibre length would be larger than fibres shorn at another point of time. With bi-annual shearing regimes fibre breaking points are unavoidable and staple strength depends on health and nutritional status along the 2 years of fibre growth. Staple strength is especially important for fibre destined to mechanical dehairing, due to the tensions imposed in the process. Further studies on the profile of fibre diameter along the staples in different production areas would help to identify the best shearing dates and shearing frequencies.

\section{Markets and processing}

The llama fibre production could easily be doubled by an increase in the number of llamas shorn and by an increase in the frequency of their shearing. The main incentive for this to happen is of course the price paid for the fibre. Llama fibre is usually sold unclassified but there are some communities in Jujuy who organize a joint offer of classed fibre (Lamas, 2013). These communities clean the fleeces from soil and other contaminations and apply a basic classing protocol based on nine colour classes and four visually assessed fibre fineness classes. Homogenous groups combining colours and fineness classes are formed and tendered. Such fibre sales fetch up to double the price an individual farmer would get for his llama fibre. Thus, classing fleeces according to quality and strengthening the handling and storage capacities of communities improve income and interest to produce better and more fibre. The physical characteristics of the camelid fibres make up its commercial value, but also do so intangible features such as the association of the fibre with particular environments and exotic cultures. Llama and vicuña fibre is often associated with the Andean highlands and the remains of the Inca-culture, whereas guanacos are associated with the vast Patagonian desert. In order to be able to exploit these intangible values, promotion and marketing skills are needed. In Argentina, there is a lack of llama producerś organizations which promote production of high-quality fibre, especially in the regions of origin.

There is a shortage of legally produced vicuña fibre for the local artisan market, where an estimated volume of $400 \mathrm{~kg}$ per year is needed. If this demand cannot be satisfied with legally obtained fibre and at a reasonable price, poaching will increase. Artisans prefer processing individual vicuña fleeces rather than bulk vicuña fibre to be able to separate more easily guard hairs and classify for fibre colour. Skilled artisans separate up to six vicuña colours from a single fleece. About one-third of the fleece is white. The different colours are spun separately into yarn which is then transformed into "Ponchos" and other popular garments using traditional looms.

Guanacos produce down fibres that are at the lower limit of fibre length that is acceptable by the textile industry. Short fibres are also difficult to spin by artisans. Most guanaco fibre samples have an average fibre length in the range $25-35 \mathrm{~mm}$ and are processed through the woollen system. With coefficients of variation of fibre length at 30 percent there is a high proportion of fibres below $10 \mathrm{~mm}$ which typically would produce pilling in finished products. Often guanaco fibres are also tender and break in the carding process and therefore reduce its yield. Thus, pure guanaco fibres are difficult to get through the combing process. Local experiences indicate that guanaco fibres 
can be successfully blended with merino wool (in for example 20:80 proportions, respectively) in order to increase spinning performance and produce high-valued products (Guenguel, 2014). Vicuñas have a slightly higher fibre length but face similar challenges as guanaco fibres. Studies to identify fibre quality differences along the fleece of guanacos of both sexes and different ages have been performed in order to detect eventual fibre classing needs (Cancino, Mueller and Giovannini, 2011). Hick et al. (2005) conclude that such classing should be based on the results of differences in dehaired fibre quality along the fleece. The cost-effectiveness of such additional work remains an open question.

Fine-tuning the shearing dates and shearing regime can improve the length, down yield and fibre diameter of these special fibres. It seems also necessary to study more guanaco and vicuña ecotypes and populations to investigate if there is a relation between fleece weight, fibre length, altitude and temperature. This knowledge would help to better target wild camelid populations for capture and shearing.

Spinning camelid fibres on farm and selling the yarn can increase profit substantially (von Thüngen and Lanari, 2010). At the community level, small-scale fibre processing plants such as the "Mini-mills" (Belfast Mini-mills, 2014) are being tested in the country. At these small scale but versatile mills, yarn and felt products are already produced with cashmere, wool and camelid fibres in various blends (Sacchero, 2014).

\section{Conclusions}

The Puna highlands in the northwest of Argentina and the vast Patagonian cold desert in the South are home to llamas, vicuñas and guanacos which produce noble fibres used by artisans and the textile industry to produce highvalued textile products. Fibre production potential is high as is further improvement of fibre quality and added value.

\section{Acknowledgement}

This review includes research financed by the National Institute for Agricultural Technology (INTA), Argentina.

\section{References}

Adot, O.G., Cossio, A.P. \& Maguire, A. 2008. Industrialization and commercialisation of vicuña, guanaco and llama fibres. In E. Frank, M. Antonini \& O. Toro, eds. South American Camelids Research, Vol. 2, pp. 359-366. The Netherlands, Wageningen Academic Publishers.

Amaya, J. \& von Thüngen, J. 2001. Cría de guanacos en semicautividad. Comunicación Técnica INTA Bariloche Nro RN 114.
Amaya, J., von Thüngen, J. \& De Lamo, D. 2001. Densidad de guana$\cos$ (Lama guanicoe) en la Patagonia. Comunicación Técnica INTA Bariloche Nro RN 109.

Amendolara, D. 2001. Manejo y uso sustentable de la vicuña en condiciones de semicautiverio en la Puna argentina. Universidad Internacional de Andalucía. Jaén, Spain, 128 p (Tesis de Maestría).

Arzamendia, Y. \& Vilá, B. 2012. The effects of capture, shearing and release on the ecology and behavior of wild vicuña. J. Wildlife Manage. 76: 54-64.

Arzamendia, Y., Baldo, J.L. \& Vilá, B. 2012. Lineamientos para un plan de conservación y uso sustentable de vicuñas en Jujuy, Argentina. Argentina, Editorial UNJU, San Salvador de Jujuy, 165 p.

Bacchi, C.S., Lanari, M.R. \& von Thüngen, J. 2010. Non-genetic factors affecting morphometric and fleece traits in guanaco (Lama guanicoe guanicoe) populations from Argentinean Patagonia. Small Rumin. Res. 88: 54-61.

Belfast Mini-mills. 2014. www.minimills.net (accessed 2014.07.14).

Cancino, A.K., Rebuffi, G.E. \& Aller, J.F. 2001a. Captura y esquila de vicuñas (Vicugna vicugna) en criaderos privados en Argentina. Encuentro: Perspectivas para el desarrollo de la ganadería de camélidos en Chile. Arica, Chile, 4-7 de septiembre.

Cancino, A.K., Rebuffi, G.E. \& Aller, J.F. 2001b. Producción de llamas en el CEA INTA Abra Pampa. Seminario sobre posibilidades de desarrollo de productos agroindustriales en el NOA, orientados a nichos de mercado. 21-22 de noviembre, Jujuy. Resúmenes de trabajos. Agencia Nacional de Promoción Científica y Tecnológica.

Cancino, A.K., Rebuffi, G.E., Mueller, J.P., Duga, L. \& Rigalt, F. 2006. Parámetros cuali-cuantitativos de la producción de fibra de llamas (Lama glama) machos en la Puna Argentina. En: M. Miragaya, D. Olivera \& S. Puig, eds. IV Congreso Mundial de Camélidos, pp. 11-15 de octubre. Eje temático 5. Producción y transformación.

Cancino, A.K., Abad, M., Taddeo, H. \& Sacchero, D. 2008. Producción de fibra de guanaco (Lama guanicoe) criados en diferentes ambientes de Río Negro. Revista Argentina de Producción Animal 28 (Supl. 1): 235-236.

Cancino, A.K., Mueller, J.P. \& Giovannini, N. 2011. Efectos que influyen en las características de calidad del vellón de guanaco. Revista Argentina de Producción Animal 31(Supl. 1): 90.

Cardellino, R.C. \& Mueller, J.P. 2009. Fiber production and sheep breeding in South America. Proc. Assoc. Adv. Anim. Breed. Genet. 18: $366-373$.

CNVG. 2007. Primer censo nacional vicuña y guanaco al norte del Río Colorado 2006. Argentina, Dirección de Fauna Silvestre.

Coates, W. \& Ayerza, R. 2004. Comparison of llama fiber obtained from two production regions of Argentina. Small Rumin. Res. 58: 513-524.

DFS. 2014. Informe República Argentina. XXXI Reunión Ordinaria de la Vicuña. Dirección de Fauna Silvestre, La Paz, Bolivia 24-26 de julio, $58 \mathrm{p}$.

Duba, M.M. 1999. Desarrollo de estrategias competitivas para la fibra de vicuña. Maestría en administración de empresas, especialidad marketing. Universidad Católica de Salta, Argentina.

FAO. 2005a. Situación actual de los camélidos sudamericanos en Argentina. Proyecto de Cooperación Técnica en apoyo a la crianza y aprovechamiento de los camélidos sudamericanos en la región andina TCP/RLA/2914. Junio, 38 p.

FAO. 2005b. Situación actual de los camélidos sudamericanos en Bolivia. Proyecto de Cooperación Técnica en apoyo a la crianza y aprovechamiento de los camélidos sudamericanos en la región andina TCP/RLA/2914. Junio, 55 p. 
Frank, E.N. \& Nuevo Freire, C.M. 1985. Estudio de la productividad de un plantel de llamas en la puna catamarqueña. Revista Argentina de Producción Animal 5: 505-512.

Frank, E.N. \& Whebe, V.E. 1993. Producción y comercialización de fibra de camélidos argentinos domésticos. En: J.P. Mueller ed. Taller sobre producción y comercialización de fibras especiales, pp. 81-96. INTA Bariloche.

Frank, E.N., Hick, M.V.H., Gauna, C.D., Lamas, H.E., Renieri, C. \& Antonini, M. 2006a. Phenotypic and genetic description of fiber traits in South American domestic camelids (llamas and alpacas). Small Rumin. Res. 61: 113-129.

Frank, E.N., Hick, M.V.H., Lamas, H.E., Gauna, C.D. \& Molina, M. G. 2006b. Effects of age-class, shearing interval, fleece and color types on fiber quality and production in Argentine llamas. Small Rumin. Res. 61: 141-152.

Frank, E.N., Hick, M.V.H. \& Adot, O. 2007. Descriptive differential attributes of type of fleeces in Llama fibre and its textile consequence: 1 - Descriptive aspects. J. Textile Inst. 98: 251-259.

Frank, E.N., Hick, M.V.H., Molina, M.G. \& Caruso, L.M. 2011 Genetic parameters for fleece weight and fibre attributes in Argentinean Llamas reared outside the Altiplano. Small Rumin. Res. 99: 54-60.

Frank, E.N., Hick, M.V.H. \& Adot, O. 2012. Determination of dehairing, carding, combing and spinning difference from llama type of fleeces. Int. J. Appl. Sci. Technol. 2: 61-70.

Guenguel. 2014. www.guenguel.com.ar/catalogos/nueva eng.htm (accessed 2014.8.1).

Hick, M.V.H., Frank, E.N., Adot, O., Maguirre, A., Seghetti, D. \& Fabbio, F. 2005. Diferenciación de regiones del vellón de guanaco en base a criterios de calidad textil. Revista Argentina de Producción Animal 25(Supl. 1): 367-368.

Hick, M.V.H., Lamas, H.E., Echenique, J., Prieto, A., Castillo, M.F. \& Frank, E.N. 2009. Estudio demográfico de los atributos morfológicos y productivos en poblaciones de llamas (Lama glama) de la provincia de Jujuy, Argentina. Anim. Genet. Resour. Inf. 45: $71-78$.

INDEC. 2002 Censo Nacional Agropecuario. Argentina, Instituto Nacional de Estadísticas y Censos.

Iñiguez, L.C., Alem, R., Wauer, A. \& Mueller, J.P. 1998. Fleece types, fiber characteristics and production system of an outstanding llama population from Southern Bolivia. Small Rumin. Res. 30: 57-65.

Lamas, H. 2013. Experiencias de acopio comunal de fibra de llama acondicionada, clasificada y tipificada en la Puna de Jujuy. Periodo 1995 2006. Actas de la I Jornada de Desarrollo y Extensión Rural en la Región Andina, INTA Abra Pampa, 7-8 de noviembre.

Lichtenstein, G. \& Carmanchahi, P.D. 2012. Guanaco management by pastoralists in the Southern Andes. Pastoralism: Res., Policy Pract. 2: 16 .

Manero, A., Dragnic, K., Clifton, G. \& Vargas, P. 2013. Relevamiento de poblaciones de guanaco en la provincia de Santa Cruz. Universidad Nacional de la Patagonia Austral, Río Gallegos, 19 p.

Maquera, E. 1991. Persistencia fenotípica y caracterización de los tipos de llama kara y lanuda. Tesis de Magister en Ciencia en Producción Animal. Universidad Nacional Agraria La Molina. Lima, Perú, 108 p.

Martinez, Z., Iniguez, L.C. \& Rodríguez, T. 1995. Influence of effects on quality traits and relationships between traits of the llama fleece. Small Rumin. Res. 24: 203-212.

McGregor, B.A. 2006. Production attributes and relative value of alpaca fleeces in southern Australia and implications for industry development. Small Rumin. Res. 61: 93-111.
MECON, 2006. Plan Nacional de Manejo del Guanaco. Res. 477/2006 Secretaria de Ambiente y Desarrollo Sustentable del Ministerio de Economía y Finanzas Públicas de la Nación. Argentina. http://infoleg.mecon.gov.ar/infolegInternet/anexos/115000-119999/116778/ norma.htm

MECON, 2010. Plan de competitividad del conglomerado camélido de la provincia de Jujuy. Secretaría de Política Económica del Ministerio de Economía y Finanzas Públicas de la Nación. Argentina. 42 p. http://www.mecon.gov.ar/programanortegrande/documentos/jujuy camelidos_pc_resumen.pdf

Mueller, J.P., Elvira, M.G. \& Sacchero, D.M. 2013. Animal fibers in Argentina: production and research. 6th Symposium on South American Camelids and 2nd European meeting on Fiber Animals. In D. Allain, ed., 64th EAAP Annual Meeting, 25-30 August, Nantes, France. Session 43, 10 p. http://www.eaap.org/ Previous_Annual_Meetings/2013Nantes/Papers/Published/S43_01.pdf

Paz, R., Sossa Valdez, F., Lamas, H., Echazu, F. \& Califano, L. 2012. Diversidad, mercantilización y potencial productivo de la Puna jujeña. Estudios del Trabajo 43/44: 49-80.

PGTF. 2013. Capacity strengthening in the field of llama production in Argentina, Bolivia and Peru. Perez Guerrero Trust Fund Project No. 19, United Nations.

PLC. 2008. Proyecto de Ley para la promoción y desarrollo de la ganadería de camélidos sudamericanos. Senado de la Nación Argentina. Expediente 1406-D-2008.

PROSAP. 2010. Desarrollo de la cadena del camélido en la Puna Catamarqueña. Resultado de encuestas. Programa de servicios agrícolas provinciales. $20 \mathrm{p}$.

Quispe, E.C., Rodríguez, T.C., Iñiguez, L.R. \& Mueller, J.P. 2009 Producción de fibra de alpaca, llama, vicuña y guanaco en Sudamérica. Animal Genetic Resources 45: 1-14.

Quispe, E.C., Ramos, H., Mayhua, P. \& Alfonso, L. 2010. Fiber characteristics of vicuña (Vicugna vicugna mensalis). Small Rumin. Res. 93: 64-66.

Rebuffi, G. 1999. Caracterización de la producción de fibra de vicuña en el altiplano argentino. Universidad de Córdoba. España, 365 p (Tesis doctoral).

Rey, A., Novaro, A.J., Sahores, M. \& Guichón, M.L. 2012. Demographic effects of live shearing on a guanaco population. Small Rumin. Res. 107: 92-100.

Rigalt, F., Rebuffi, G., Vera, R. \& Pivotto, R. 2006a. Caracterización preliminar de la calidad de fibra de vicuña (Vicugna vicugna) de la reserva Laguna Blanca, Catamarca, Argentina. En: M. Miragaya, D. Olivera \& S. Puig, eds. IV Congreso Mundial de Camélidos. Resúmenes, p. 79.

Rigalt, F., Sabadzija, G. \& Rojas, M. 2006b. Análisis económico del sistema de uso en silvestría de vicuñas en la reserva de Laguna Blanca, Catamarca, Argentina. En: M. Miragaya, D. Olivera \& S. Puig, eds. IV Congreso Mundial de Camélidos. Eje temático 6. Economía.

Roisinblit, D. 2011. Mapa de desarrollo de Jujuy. Primera Edición. Ministerio de Economía y Finanzas Públicas. Subsecretaría de Relaciones con Provincias, Buenos Aires, Argentina, 90 p.

Sacchero, D.M. 2014. Minimills, una alternativa de pequeña escala para agregar valor a las fibras textiles. Presencia 61: 15-18.

Sacchero, D.M. \& Mueller, J.P. 2005. Determinación de calidad de vellones de doble cobertura tomando al vellón de vicuña (Vicugna vicugna) como ejemplo. Revista de Investigaciones Agropecuarias 34: $143-159$

Sacchero, D.M., Maurino, M.J. \& Lanari, M.R. 2006. Diferencias de calidad y proporción de down en muestras individuales de vellones 
de guanacos (Lama guanicoe) en distintas ecoregiones de Argentina Revista Argentina de Producción Animal 26: 211-216.

Siguayro, R.P. \& Aliaga, J.L. 2009. Comparación de las características físicas de las fibras de la llama ch'aku y la alpaca huacaya. http:/ www.monografias.com/trabajos82/comparacion-fibras-llama-y-alpaca/ comparacion-fibras-llama-y-alpaca.shtml

Stemmer, A., Valle Zárate, A., Nürnberg, M., Delgado, J., Wurzinger, M. \& Sölkner, J. 2005. La llama de Ayopaya: descripción de un recurso genético autóctono. Archivos de Zootecnia 54: 253-359.

Von Thüngen, J. \& Lanari, M.R. 2010. Profitability of sheep farming and wildlife management in Patagonia. Pastoralism 1: 274-290.
Von Thüngen, J., Gálvez, C.M., Sacchero, D. \& Duga, L. 2005. Análisis de calidad de la fibra de guanaco (Lama guanicoe M.) en la Patagonia. Revista Argentina de Producción Animal 25(Supl. 1): 382-383.

Von Thüngen, J., Lheure, R., Seguineau De Preval, E. \& Perazzo, A. 2012. External effects for the quantity and quality of fiber in guanacos. In M.A. Perez-Cabal, J.P. Gutierrez, I. Cervantes \& M.J. Alcalde, eds. Fiber Production in South American Camelids and other Fiber Animals, pp. 43-49. Wageningen Academic Publishers.

Wurzinger, M., Delgado, J., Nürnberg, M., Valle Zárate, A., Stemmer, A., Ugarte, G. \& Sölkner, J. 2006. Genetic and nongenetic factors influencing fibre quality of Bolivian llamas. Small Ruminant Research 61: 131-139. 